\title{
Effects of unilateral hypothalamic lesions on drinking and self-stimulation in the rat'
}

\author{
A. G. PHILLIPS AND G. J. MOGENSON \\ UNIVERSITY OF WESTERN ONTARIO
}

A series of rats were lesioned unilaterally through hypothalamic electrodes from which drinking and self-stimulation could be elicited. The lesions abolished electrically-induced drinking and severely reduced rates of self-stimulation. In addition, a transient adipsia and hypophagia resulted from lesioning in several of the animals.

The neural systems for the control of water intake appear to have a critical focus in the hypothalamus. Electrical stimulation of a site in the lateral hypothalamus (LH) just dorsolateral to the fornix induces satiated rats to drink water (Mogenson \& Stevenson, 1967). This site is located approximately $1 / 2 \mathrm{~mm}$ medial to the region which has been lesioned bilaterally to produce adipsia (Montemurro \& Stevenson, 1957). It appears that both electrical stimulation and lesions are influencing neurons which subserve the regulation of water intake but, to date, there has been no investigation of the effects of electrical stimulation and lesions of the LH in the same animal.

Recently it was reported that adipsia can be produced by unilateral lesions of the LH (Gold, 1966). Utilizing a preparation in which electrical stimulation of the $\mathrm{LH}$ induced both self-stimulation and drinking (Mogenson \& Stevenson, 1966), small unilateral lesions were placed at the tip of the electrode in an attempt to produce adipsia. The effects of such lesions on self-stimulation were also studied.

\section{Method}

Ten male Wistar rats, 11-13 months of age, which could be induced to drink by electrical stimulation of the LH (de Groot coordinates, $A=5.0, L=1.7, V=3.0$ ), were placed on an ad lib high carbohydrate diet and water. This diet was employed because it could be placed in spill-proof jars to facilitate the measurement of food intake. Twenty-four $h$ intakes of food and water were recorded. Aphagia and adipsia were defined as the consumption of $2.0 \mathrm{~g}$, or less, of food and water per day.

Fifteen days after the new diet was made available, five Ss were lightly anesthetized with ether and lesioned, by passing a $1 \mathrm{~mA}$ current for $10 \mathrm{sec}$ between both wires of the stimulating electrode and a cathode in the anus. As a control for the effects of ether three additional Ss were anesthetized with ether, but not lesioned. Food and water intakes were measured for the next seven days to determine the effects of the lesions. On the eighth day the Ss, which had served as controls, were lesioned in the same manner and food and water intakes were measured for the next week.

After the effects on food and water intake were assessed, the Ss were retested for self-stimulation and electrically-induced drinking. In the first session the current settings which had originally elicited drinking and self-stimulation were used. During the next three daily 30 min sessions the intensities were gradually increased five fold to check for changes in threshold.

At the completion of the experiment the rats were anesthetized, bled and perfused with normal saline and $10 \%$ formalin. The brains were then removed,

Table I.

Prelesion and postlesion food and water intakes.

\begin{tabular}{|c|c|c|c|c|c|c|c|c|c|c|}
\hline \multirow[b]{3}{*}{$\begin{array}{c}\text { Subject } \\
\text { No. }\end{array}$} & \multicolumn{4}{|c|}{ Prelesion Intakes } & \multirow{3}{*}{ LESION } & \multicolumn{4}{|c|}{ Postlesion Intakes } & \multirow[b]{3}{*}{ Effect } \\
\hline & \multicolumn{2}{|c|}{$48 \mathrm{~h}$} & \multicolumn{2}{|c|}{$24 \mathrm{~h}$} & & \multicolumn{2}{|c|}{$24 \mathrm{~h}$} & \multicolumn{2}{|c|}{$48 \mathrm{~h}$} & \\
\hline & $\begin{array}{c}\text { Food } \\
\text { (g) }\end{array}$ & $\begin{array}{c}\text { Water } \\
\text { (ml) }\end{array}$ & Food & Water & & Food & Water & Food & Water & \\
\hline$P-6$ & 25 & 17 & 25 & 18 & & 2 & 0 & 7 & 8 & Adipsia \\
\hline P-3 & 15 & 16 & 18 & 17 & & 3 & 1 & 16 & 14 & and \\
\hline P-10 & 23 & 23 & 23 & 24 & & 4 & 2 & 25 & 25 & Hypophagia \\
\hline$p_{-4}$ & 24 & 20 & 26 & 14 & & 13 & 7 & 17 & 14 & Hypodipsia \\
\hline P-5 & 23 & 12 & 24 & 17 & & 13 & 7 & 16 & 16 & and \\
\hline P-7 & 20 & 20 & 20 & 20 & & 10 & 12 & 18 & 23 & Hypophagia \\
\hline P-8 & 28 & 24 & 28 & 23 & & 20 & 10 & 22 & 26 & Hypodipsia \\
\hline P.9 & 22 & 18 & 23 & 18 & & 20 & 17 & 22 & 18 & \\
\hline P-1 & 16 & 13 & 20 & 17 & & 16 & 20 & 15 & $\begin{array}{l}10 \\
15\end{array}$ & No \\
\hline P-2 & $\begin{array}{l}10 \\
19\end{array}$ & 15 & 26 & 18 & & 22 & 16 & 18 & 14 & Effect \\
\hline
\end{tabular}


Table 2.

Mean prelesion and postlesion

self-stimulation thresholds and lever pressing rates.

\begin{tabular}{cccc}
$\begin{array}{c}\text { Prelesion threshold } \\
\text { intensity }\end{array}$ & $\begin{array}{c}\text { Postlesion threshold } \\
\text { intensity }\end{array}$ & $\begin{array}{c}\text { Prelesion } \\
\text { rate/30 min }\end{array}$ & $\begin{array}{c}\text { Postlesion } \\
\text { rate/30 min }\end{array}$ \\
\hline$\overline{\mathrm{X}}=35 \mu \mathrm{A}$ & $\overline{\mathrm{X}}=133 \mu \mathrm{A}$ & $\overline{\mathrm{X}}=612$ & $\overline{\mathrm{X}}=124$
\end{tabular}

fixed in $10 \%$ formalin, sectioned at $15 \mu$ and stained with cresyl violet.

\section{Resulis}

Unilateral lesions made through the stimulating electrode reduced the food and water intake of seven of the 10 experimental animals. As can be seen in Table 1, during the first $24 \mathrm{~h}$ following lesioning, three Ss were adipsic and very hypophagic, three Ss were hypodipsic and hypophagic, and one was hypodipsic. The lesions had no effect on three of the Ss. Examination of the histological results showed that two of the Ss (No. P1 and P2) in which no effect was observed, had more anterior electrodes placements than the other Ss. Both of these Ss also drank the smallest volumes of water during the electrically-induced drinking session. The remaining electrode placements were located in a region dorsolateral to the fornix, between A. P. 4.7-5.0 (deGroot, 1959). A significant Spearman Rank Order Correction $(\mathrm{r}=.643, \mathrm{p}<.05)$ was obtained between (a) the effectiveness of the lesion, determined by the reduction in water intake and (b) the amount of water consumed during the $30 \mathrm{~min}$ electricallyinduced drinking session.

Postlesion self-stimulation thresholds were four to five times greater than the prelesion thresholds (see Table 2). This was the case with all Ss, indicating that the lesions were effective. The increased stimulation thresholds were accompanied by much lower self-stimulation rates (see Table 2) suggesting that crucial tissue for self-stimulation had been destroyed.

\section{Discussion}

The concept of LH regulation of water intake is based on the findings that lesions in this area produce adipsia (Montemurro \& Stevenson, 1957), while electrical and chemical stimulation induce drinking (Mogenson \& Stevenson, 1966; Grossman, 1960). These results suggest that electrical stimulation and lesions are influencing a common locus. The fact that transient adipsia resulted from unilateral lesioning of a site from which electrically-induced drinking could be elicited confirms this hypothesis.

The effects on food and water intake were temporary, with intakes returning to prelesion levels $24-48 \mathrm{~h}$ after the lesion. This result confirms the observations of Gold (1966, 1967) who reported an aphagia and adipsia which lasted an average of 1.3 days. It should be noted that the lesions affected both feeding and drinking while the electrical stimulation only elicited drinking. This may have occurred because rats eat less when they cannot drink (Epstein \& Teitelbaum, 1964).

The lesions completely eliminated electricallyinduced drinking despite repeated tests over a wide range of stimulus intensities $(10-200 \mu \mathrm{A})$. The critical focus for electrically-induced drinking is probably quite small and localized; the histological results suggest an area of no more than $2 \mathrm{~mm}$ in diameter. The lesions also severely disrupted self-stimulation which could be elicited from the same electrode site. Postlesion self-stimulation thresholds were greatly increased and the rates reduced, indicating the destruction of critical tissue for self-stimulation. The fact that postlesion self-stimulation could still be elicited suggests, however, that many more neurons were involved in self-stimulation than in electricallyinduced drinking. Valenstein (1967) obtained similar effects on self-stimulation with small lesions; however, he reports that a larger lesion at the electrode tip produced by $2.0 \mu \mathrm{A}$ of direct current completely abolished self-stimulation behavior. The finding that a small lesion can destroy electrically-induced drinking, while only impairing self-stimulation, implies a degree of independence between the neural system subserving self-stimulation and the homeostatic control systems.

\section{References}

de GROOT, J. The rat forebrain in stereotaxic co-ordinates. Amsterdam: N-V Noord. Hollandsche Vitgevers Mattschapij, 1959.

EPSTEIN, A. N., \& TEITELBAUM, P. Severe and persistent deficits in thirst produced by lateral hypothalamic damage. In M. J. Wayner (Ed.), Thirst. Oxford: Pergamon Press, 1964, 395 410.

GOLD, R. M. Aphagia and adipsia produced by unilateral hypothalamic lesions in rats. Amer. J. Physiol., 1966, 211(5), 1274-1276.

GOLD, R. M. Aphagia and adipsia following unilateral and bilateral asymetrical lesions in rats. Physiol \& Behav., 1967, 2(2), 211-220.

GROSSMAN, S. P. Eating and drinking elicited by direct adrenergic or cholinergic stimulation of the hypothalamus. Science, 1960, 132, 301-302.

MOGENSON, G. J., \& STEVENSON, J. A. F. Drinking and selfstimulation with electrical stimulation of the lateral hypothalamus. Physiol. \& Behav., 1966, 1, 251-254.

MOGENSON, G. J., \& STEVENSON, J. A. F. Drinking induced by electrical stimulation of the lateral hypothalamus. Exp. Neurol., 1967, 17, 119-127.

MONTEMURRO, D. G., \& STEVENSON, J. A. F. Adipsia produced by hypothalamic lesions in the rat. Canad. J. Biochem. Physiol., 1957, 35, 31-37.

VALENSTEIN, E. S. The anatomical locus of reinforcement. In M. E. Stellar and J. M. Sprague (Eds.), Progress in Physiological Psychology. New York, Academic Press, 1966, 149-190.

Note

1. This study was supported by grants from the M.R.C. and the N.R.C. of Canada. 